\title{
ANÁLISE DE CAPAS E CONTRA-CAPAS DE “MARXISMO E FILOSOFIA DA LINGUAGEM” EM DUAS TRADUÇÕES: VALORAÇÃO E DIALOGISMO
}

\author{
ANALYSIS OF "COVERS" AND "BACK COVERS" OF "MARXISM AND \\ PHILOSOPHY OF LANGUAGE" BOOK IN TWO TRANSLATIONS: VALUATION \\ AND DIALOGISM
}

\begin{abstract}
Ludmila Kemiac ${ }^{94}$
RESUMO: Neste artigo, analisamos a dimensão verbal e não verbal de capas e contracapas de "Marxismo e filosofia da linguagem", na edição da Hucitec e da editora 34, segundo pressupostos teóricos do Círculo de Bakhtin e ancorados em categorias da semiótica discursiva. Especificamente, considerando que o Círculo centrou suas análises sobretudo em textos verbais (principalmente literários), procuramos definir algumas categorias para a análise de textos de materialidade semiótica distinta (verbo-visual). Para tanto, em um primeiro momento, apresentamos reflexões sobre o texto enquanto objeto semiótico. Em seguida, apresentamos características do gênero "capa" e "contracapa" de livro, para, posteriormente, analisarmos as capas e contracapas da obra "Marxismo..." publicada pela Hucitec e pela editora 34. Por fim, concluímos que capas e contracapas de livros condensam valores de um tempo (o valor de mercado e de consumo, através do apelo à diferenciação do produto) e estabelecem modos específicos de recepção do texto.
\end{abstract}

PALAVRAS-CHAVE: Marxismo e filosofia da linguagem. Capas e contracapas de livro. Texto verbo-visual.

\begin{abstract}
In this article, we analyze the verbal and nonverbal dimensions of "Marxism and philosophy of language" in the edition of Hucitec and in the edition of "editora 34", according to theoretical assumptions of the Bakhtin's Circle and anchored in some categories of discursive semiotics. Specifically, considering that Bakhtin's Circle centered theirs analysis mainly on verbal (literary) texts, we tried to define some categories for the analysis of texts of distinct semiotic materiality (verb-visual). To do so, at first, we present some reflections on the text as a semiotic object. Next, we present some characteristics of the genre "cover" and "back cover" of books. Later, we analyze covers and back covers of the "Marxism ...", which was published by Hucitec and "editora 34". Finally, we conclude that book covers and back covers summarize values of an epoch (market and consumer value, through the call to product differentiation) and establish specific modes of text reception.
\end{abstract}

KEYWORDS: Marxism and philosophy of language. Book covers and back covers. Verbo-visual text.

\section{Introdução}

Publicada inicialmente na Rússia em 1929, sob autoria de V. Volóchinov, a obra "Marxismo e filosofia da linguagem" foi posteriormente atribuída a M. Bakhtin, sendo, no Brasil, divulgada pela Editora Hucitec. Em 2017, a editora 34 lança a versão de "Marxismo..." traduzida diretamente do russo, com a autoria creditada a Volóchinov. A questão da autoria ainda polêmica e tratada com cautela -, a recepção da obra, a temporalidade dessa recepção (dentre outros aspectos) encontram-se refratados na materialidade das capas e contracapas da obra em suas diferentes traduções.

Nesse sentido, este artigo busca, como objetivo geral, estabelecer um diálogo entre as estratégias de manifestação e de organização da materialidade textual (verbal + visual) com os valores, as finalidades e a temporalidade refletida e refratada no texto, dentro de sua esfera social. Para tanto, analisamos as capas e contracapas de "Marxismo e filosofia da linguagem", na edição da Hucitec e da editora 34.

Dividimos este artigo em outras quatro partes além da presente introdução: no tópico 2, apresentamos algumas reflexões sobre o texto enquanto objeto semiótico, bem como propomos, no subtópico 2.1, categorias para a análise de textos verbo-visuais. No tópico 3,

${ }^{94}$ Professora de Língua Portuguesa da Universidade Federal de Campina Grande. Doutoranda em Linguística pelo Programa de Pós-Graduação em Linguística (PROLING) da Universidade Federal da Paraíba (e-mail para contato: ludmila_kemiac@hotmail.com). 
apresentamos algumas características do gênero "capa" e "contracapa" de livro, para, em seguida, no tópico 4, analisarmos as capas e contracapas da obra "Marxismo..." publicada pela Hucitec e pela editora 34. Por último, tecemos considerações finais no tópico 5.

\section{0 estatuto do texto ${ }^{95}$ e problema do material - o material semiotizado}

O título desta seção é ambíguo, pois remete, à primeira vista, ao ensaio escrito por M. Bakhtin em 1924, a saber: "O problema do conteúdo, do material e da forma na criação literária" (BAKHTIN, 2002 [1924]); ao mesmo tempo, com esse título, queremos abordar uma questão que não constituiu objeto de análise detalhada do chamado "Círculo de Bakhtin": a natureza específica, a materialidade de textos que combinam semioses diversas, a exemplo dos textos verbo-visuais.

Segundo Faraco (2009, p. 16), no conjunto da obra do Círculo, “(...) é perceptível a existência de dois grandes projetos intelectuais. Da parte de Bakhtin, parece haver, de início, a intenção de construir uma 'prima philosophia'”. Assim, os primeiros textos, notadamente "Para uma filosofia do ato responsável" (BAKHTIN, 2010 [1919-1921]), criticam, sobretudo, o teoreticismo, "as objetificações da historicidade vivida" (FARACO, 2009, p. 16). O segundo projeto, conforme Faraco (2009, p. 17), visível em Volóchinov e Medviédev, entre 1925 e 1930, "era contribuir para a construção de uma teoria marxista da chamada criação ideológica". A linguagem - e as diversas interlocuções com a linguística -, segundo assinala Faraco (op. cit.), torna-se central nos textos posteriores a 1926.

Centrados na linguagem como elemento essencial de suas reflexões, Volóchinov, Bakhtin e Medviédev debruçam-se sobre o estudo das ideologias - com forte acentuação sociológica -, da literatura, da estética. Há diálogos e críticas, nos textos do Círculo, à Linguística contemporânea, porém, o objeto de reflexão, percebe-se, centra-se principalmente na linguagem verbal.

Bakhtin, no ensaio anteriormente citado de 1924 (BAKHTIN, 2002 [1924]), propõe o que ele denomina como "estética sistemática e geral" (p. 13) para analisar metodologicamente conceitos da poética. Suas críticas são tecidas principalmente aos formalistas russos, nesse ensaio. Nele, Bakhtin aborda questões pertinentes acerca da materialidade do objeto estético, de forma geral, e do objeto estético poético, em particular. Essas reflexões são importantes para o que adiante desenvolveremos, uma vez que definem a materialidade do objeto estético como uma materialidade semiotizada.

Na terceira parte de seu ensaio (“O problema do material”), Bakhtin (2002 [1924]) defende que o elemento técnico "é indispensável à criação na sua determinação físicomaterial ou linguística" (p. 49), mas, enquanto tal, não entra no objeto estético "acabado". Utiliza o autor uma interessante metáfora: os andaimes de um prédio em construção desaparecem quando ele está pronto. Nesse sentido, embora a língua constitua o "aparato técnico", a "materialidade" da poesia, deve-se entendê-la como algo "além do material". A língua, na poesia, é o material "apropriado" pelo artista, conforme afirma Faraco (2016) - a língua é a materialidade da poesia não como soma de fonemas, morfemas, sintagmas (embora morfemas, fonemas etc sejam sim parte da língua), mas como um "todo valorativo", um objeto verbo-axiológico recortado do mundo da vida, reorganizado e transposto para o mundo estético pelo autor-criador. Em outras palavras, a materialidade da poesia - a língua constitui um objeto semiótico.

Essa ideia de semiotização defendida por Bakhtin no ensaio de 1924, acerca da materialidade do objeto estético, é estendida para se pensar a materialidade de qualquer texto,

95 O termo "texto", empregado neste artigo, recobre o segundo pólo definido por Bakhtin no ensaio "O problema do texto", constante da obra "Estética da criação verbal" (BAKHTIN, 2003), isto é, o texto como enunciado. 
considerando que essa tese é fortemente defendida por Volóchinov e Mediédev. Na visão do Círculo, não temos acesso direto ao mundo físico, pois esse mundo nos chega pela linguagem, pelo signo ideológico, cuja "pureza semiótica" (VOLÓCHINOV, 2009 [1929]) o faz onipresente em todas as esferas humanas.

Em Medviédev (2012, p. 48), lemos que as obras de arte, os trabalhos científicos, os ritos da religião, ou seja, "os produtos da criação ideológica" são objetos materiais de um tipo especial. Segundo o autor, esses produtos "tornam-se realidade ideológica somente quando realizados (...) em algum material em forma de um signo determinado. Por meio desse material, eles tornam-se parte da realidade que circunda o homem". (MEDVIÉDEV, 2012, p. 48-49).

As ideias defendidas por Medviédev em muito se aproximam daquelas defendidas por Volóchinov. Com efeito, conforme afirmamos acima, com base em Faraco (2009), ambos objetivavam construir uma teoria marxista da ideologia. Volóchinov constrói essa teoria notadamente em "Marxismo e filosofia da linguagem". Interessa-nos, porém, desse autor, principalmente a abordagem conferida ao estatuto do texto/enunciado e sua materialidade nos ensaios "Estrutura do enunciado" e "Discurso na vida e discurso na arte", pois, nesses ensaios, encontramos as bases para adiante formularmos uma proposta metodológica para a análise de textos cuja materialidade não é apenas verbal. Detenhamo-nos, pois, nesses ensaios.

"Estrutura do enunciado" data de 1930; "Discurso na vida e discurso na arte", de 1926. Nesses textos, encontramos o autor definindo o enunciado como unidade real de comunicação, enfatizando sua natureza social e o explorando em o que podemos chamar de "dupla estrutura" (verbal e não verbal / verbal e subentendido). Em "Estrutura do enunciado" (1930), o filósofo defende que o enunciado apresenta duas partes: uma verbal, constituída pela entonação (expressão da avaliação social), pela escolha lexical e pela disposição dessa escolha; uma extraverbal (subentendida), constituída pelo auditório e pela "situação" - esta última englobando o espaço/tempo no qual se encontram os interlocutores, o tema ou objeto, a posição desses perante o objeto de discurso. Esquematicamente:

Quadro 1 - A estrutura do enunciado

\begin{tabular}{|l|l|}
\hline \multirow{5}{*}{ ENUNCIADO } & $\begin{array}{l}\text { PARTE EXTRA-VERBAL } \\
\text { Espaço/tempo } \\
\text { Objeto ou tema } \\
\text { Posição dos interlocutores perante o objeto }\end{array}$ \\
\cline { 2 - 2 } & $\begin{array}{l}\text { PARTE VERBAL } \\
\text { Entonação } \\
\text { Escolha lexical } \\
\text { Disposição das escolhas lexicais }\end{array}$ \\
\hline
\end{tabular}

Fonte: elaboração nossa.

Para o autor, há uma codeterminação entre a parte verbal e a extraverbal do enunciado. A parte extraverbal "determina o sentido da sua primeira parte (verbal)" (p. 10). O verbal, porém, "não reflete, como um espelho, o extraverbal" (p.11), antes, "constitui, de fato, sua resolução, ela completa a avaliação, e ela apresenta, ao mesmo tempo, a condição necessária ao seu posterior desenvolvimento ideológico" (p.11).

Em "Discurso na vida e discurso na arte", Volochínov (1926, p. 6) objetiva "alcançar um entendimento do enunciado poético, como uma forma desta comunicação estética especial". Para tanto, julga necessário "antes analisar em detalhes certos aspectos dos enunciados verbais fora do campo da arte" (op. cit., p. 6). Nesse ensaio, o autor mostra como o discurso verbal não é autossuficiente, pois este "nasce de uma situação pragmática 
extraverbal e mantém a conexão mais próxima possível com essa situação" (p. 6). Mais uma vez, temos, aqui, a dicotomia presente em "Estrutura do enunciado" entre o verbal e o extraverbal, que se apresentam como constitutivos do enunciado, e indissociáveis um do outro. $\mathrm{O}$ autor argumenta que o extraverbal faz emergir o verbal - ambos mantendo estreita conexão.

Se voltarmos, porém, ao esquema 1, que resume a visão do teórico acerca da estrutura do enunciado, perceberemos que as ideias de Volóchinov foram formuladas pensando o texto/enunciado cuja materialidade é linguístico-verbal - oral ou escrito. Apenas em um texto verbal temos escolhas lexicais, disposição dessas escolhas, entonação. Um texto pictórico não se vale do léxico e um texto que une imagem e palavra, como uma propaganda em uma revista, por exemplo, dispõe, em seu interior, muito mais que palavras. Como analisar, então, textos de semioses diversas, considerando sua materialidade? Como analisar esses textos, entendendo que o material - não verbal, verbo-visual, multissemiótico - reflete e refrata, apresenta uma "resolução" das condições sócio-históricas de sua produção? No próximo subtópico, apresentamos uma proposta para responder a esses questionamentos, centrandonos, principalmente nos textos verbo-visuais, que constituem objeto de análise deste artigo.

2.1 Elementos para se pensar a materialidade de textos verbo-visuais e textos de materialidades diversas

Neste subtópico, apresentamos uma proposta teórico-metodológica para analisar textos de materialidades verbais e textos que se semiotizam através de signos de natureza das mais diversas, bem como textos que combinam uma pluralidade de semioses. Adiante, no tópico 4, apresentamos uma análise de textos verbo-visuais (capas de livros).

Nossa proposta assume o princípio da semiotização do real, preconizada pelo Círculo de Bakhtin, conforme exposto anteriormente. Segundo Volóchinov (2009 [1929, p. 36]), a realidade só existe para o homem - para a consciência humana - como realidade semiotizada ("Se privarmos a consciência de seu conteúdo semiótico e ideológico, não sobra nada"). Adiante, no mesmo texto, Volóchinov (op. cit.) atribui ao signo verbal - por ele designado como "palavra" - o estatuto de "pureza semiótica" que o coloca em primeiro plano no estudo das ideologias. Vejamos:

Cada um dos demais sistemas de signos é específico de algum campo particular da criação ideológica. Cada domínio possui seu próprio material ideológico e formula signos e símbolos que lhe são específicos e que não são aplicáveis a outros domínios. O signo, então, é criado por uma função ideológica precisa e permanece inseparável dela. A palavra, ao contrário, é neutra em relação a qualquer função ideológica específica. Pode preencher qualquer espécie de função ideológica: estética, científica, moral, religiosa. (VOLÓCHINOV, 2009 [1929], p. 36).

Concordamos com o autor acerca da onipresença da palavra nos mais diversos campos da comunicação discursiva (estética, científica etc), devido à sua "neutralidade", no sentido de servir a qualquer função ideológica. Com efeito, a linguagem verbal é responsável por nos tornar o que somos, está na base na hominização. Logo, é natural que a linguagem verbal, instrumento semiótico, acompanhe o homem em suas atividades, em todas suas esferas. Concordamos, também, que há signos não verbais, formulados no interior de uma esfera específica, e que se tornam "próprios" dessa esfera, impossíveis de serem "transferidos" para outra esfera sem um rearranjo de seus sentidos. Todavia, devemos entender que a sociedade humana vive uma saturação de semioses, com seus hipertextos, com sua simbolização máxima do real - objetificado pela imaterialidade das transações financeiras, por exemplo. 
Assim, se não vivemos em um mundo puramente verbal, é necessário que pensemos sobre como sistematizar e estudar textos, de materialidades as mais diversas, que nos cercam.

A proposta abaixo baseia-se principalmente nos dois ensaios de Volóchinov anticitados ("A estrutura do enunciado" e "Discurso na vida e discurso na arte"). Inspiramo-nos, também, no ensaio de Bakhtin, "O problema do conteúdo, do material e da forma na criação literária", também citado anteriormente. Nesse ensaio, Bakhtin (2002 [1924], p. 23) propõe que a estética analise o seu objeto em três momentos, assim assinalados: " $a$ ) o objeto estético, b) o dado material, extra-estético da obra, c) a organização composicional do material, concebida teleologicamente". Temos, pois, a ordem: conteúdo, material, forma - entendendo-se por "conteúdo" não o objeto referencial, mas "a rede de relações axiológicas" (FARACO, 2016, p. 103), “(...) o modo como são ordenados pelo autor-criador os constituintes éticos e cognitivos recortados (isolados), (...) consumados numa nova unidade de sentidos e valores" (FARACO, op. cit. p. 103). O material, por sua vez, conforme enfatizado acima, é concebido como material semiotizado e "conquistado", "apropriado" pelo autor, segundo seu projeto enunciativo. A forma composicional, por fim, é vista como o arranjo do material, que, devido à recorrência das atividades humanas, tende a certa estabilização genérica.

Destacamos que, se queremos entender o modo de funcionamento dos textos nas mais diversas esferas humanas, precisamos considerar essa esfera, os valores imbricados, o espaço/tempo de interação e não apenas o modo como o autor apropria-se dos valores sociais e os materializa, mas também a relação desse autor com seu interlocutor. Chegamos, pois, ao seguinte esquema para a "Estrutura do enunciado":

Quadro 2 - Releitura de "A estrutura do enunciado"

\begin{tabular}{|c|c|c|c|}
\hline \multicolumn{4}{|c|}{ A ESTRUTURA DO ENUNCIADO } \\
\hline \multicolumn{4}{|c|}{ I - A dimensão sociocultural } \\
\hline \multicolumn{2}{|c|}{ Relação entre interlocutores } & \multicolumn{2}{|c|}{$\begin{array}{l}\text { Como ocorre a relação entre os interlocutores: de } \\
\text { forma imediata; distante; mediada etc }\end{array}$} \\
\hline \multicolumn{2}{|c|}{ Espaço/tempo } & \multicolumn{2}{|c|}{$\begin{array}{l}\text { O espaço/tempo da interação "projetados" no } \\
\text { enunciado como valores sociais. }\end{array}$} \\
\hline \multicolumn{2}{|c|}{ Valores socioculturais presumidos e "apropriados" } & \multicolumn{2}{|c|}{$\begin{array}{l}\text { A forma como os valores sociais são apropriados } \\
\text { pelo autor. }\end{array}$} \\
\hline \multicolumn{4}{|c|}{ II - A dimensão "Forma/Material" } \\
\hline \multirow{4}{*}{ Materialidade semiótica } & \multicolumn{2}{|c|}{ Verbal } & $\begin{array}{l}\text { Signos linguísticos (ex: poemas, } \\
\text { contos, artigos etc) }\end{array}$ \\
\hline & \multicolumn{2}{|c|}{ Não-Verbal } & $\begin{array}{c}\text { Signos sonoros (a música). } \\
\text { Signos pictóricos (a pintura, a } \\
\text { fotografia etc) etc }\end{array}$ \\
\hline & \multicolumn{2}{|c|}{ Verbo-visual } & $\begin{array}{l}\text { Interdeterminação de Signos } \\
\text { linguísticos + Signos pictóricos } \\
\text { (charges, propagandas etc) }\end{array}$ \\
\hline & \multicolumn{2}{|c|}{ Multissemiótica } & $\begin{array}{l}\text { Interdeterminação de signos de } \\
\text { naturezas diversas (ex: alguns } \\
\text { textos digitais hipermídia). }\end{array}$ \\
\hline \multicolumn{4}{|c|}{ 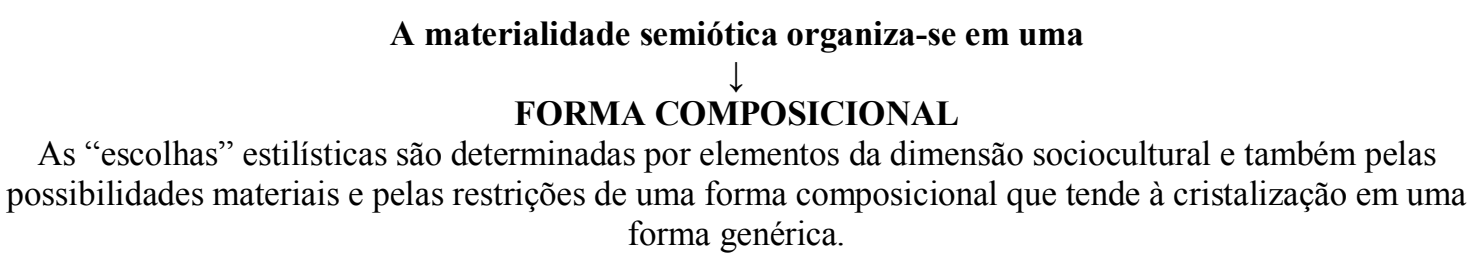 } \\
\hline
\end{tabular}


Primeiramente, considera-se que o texto em seu segundo pólo - isto é, o texto como enunciado - é um "todo" significante e irrepetível. Os elementos da dimensão social e aqueles que constituem sua forma/materialidade não são dissociáveis desse todo significante. Assim, o esquema acima possui fins didáticos e analíticos.

Em segundo lugar, assumimos, com base em Volóchinov (1926; 1930), que a dimensão sociocultural determina o sentido da segunda dimensão. A forma/material não reflete a primeira dimensão, mas constitui o que Volóchinov denomina com "resolução", o acabamento de uma avaliação. Não há reflexo, como um espelho, mas uma refração das condições socioculturais. Deve-se considerar, também, que a forma/material são "apropriadas" pelo autor criador, que projeta valores no material de que se apropria. Ao mesmo tempo, a expressão desses valores sofre coerções do material apropriado. Expliquemonos: um texto pictórico, apropriado, impõe restrições ao que é expresso nessa materialidade restrições dadas pelas possibilidades de expressão (pensemos: não há palavras. O que precisar ser expresso não encontrará o signo verbal, mas signos de outra natureza) e pela "rede" de textos da mesma natureza semiótica que estabelecem diálogos sobre temas e estilos.

O Círculo de Bakhtin centrou-se sobretudo na análise da literatura e descreveu muito bem as formas de funcionamento dessa esfera - caracterizada, dentre outros, por: 1. refratar conteúdos previamente refratadas; 2. reelaborar esteticamente esses conteúdos segundo um princípio de exotopia; 3. refratar ideologias não plenamente sedimentadas. Mas, reiteramos, que a "matéria prima", o material dessa esfera é a linguagem verbal. Logo, muito foi dito sobre esse material semiótico - o signo linguístico - e algumas lacunas ficaram para serem preenchidas a respeito de outras materialidades semióticas. Nesse sentido, considerando que outras disciplinas, a exemplo da semiótica discursiva, muito tem se debruçado sobre outras materialidades que aquelas não propriamente verbais, buscamos nessa disciplina alguns elementos para a análise de textos verbo-visuais (nosso objeto analisado, adiante, neste artigo), denominados, pela semiótica discursiva, como "textos sincréticos".

Embora a semiótica apresente uma abordagem do texto que não coaduna com nossa visão, nessa disciplina encontramos categorias interessantes para analisar a materialidade de textos que não se valem exclusivamente da linguagem verbal, mas de uma pluralidade semiótica que se condensa em uma só enunciação. Trata-se das categorias plásticas cromáticas topológicas e eidéticas, muito observadas pela vertente semissimbolista da semiótica.

Conforme Silva (2014, p. 241), as categorias eidéticas (forma) "são combinações de linhas e volumes, concretizando contrastes como côncavo x convexo, curvilíneo x retilíneo, uniforme x multiforme, ascendente x descendente, parcial x inteiro, etc". As categorias cromáticas (cor e luz) "estabelecem-se em oposições como puro x mesclado, brilhante x opaco, claro x escuro, etc". As categorias topológicas, por fim, "organizam os elementos considerando a posição e a orientação das formas, realizando-se em contrastes como englobante x englobado, alto x baixo, central x periférico, esquerdo x direito, etc". (SILVA, op. cit, 2014, p. 241)

Olivera (2004) interpreta essas categorias plásticas associando-as a um "nível profundo" de expressão dos textos. Para a autora, em um nível superficial teríamos os ícones e em um nível intermediário as figuras. As categorias plásticas, portanto, seriam traços não figurativos que dão suporte às figuras. Como não adotamos uma visão de texto que se processa em "camadas", segundo um percurso gerativo - inicialmente abstrato ("fundamental"), passando por um nível intermediário, até chegar a um nível concreto de temas e figuras -, mas o texto como enunciado, conforme a visão bakhtiniana (detalhada no esquema 2, anteriormente exposto), pensamos que as categorias plásticas devem ser concebidas não em um nível "profundo", "elementar", mas como traços estilísticos expressos na dimensão forma/material do esquema 2 supracitado. Trata-se de traços que são apropriados 
pelo autor, segundo um projeto enunciativo, expressam valores sociais, sofrem coerções do material e estruturam-se em uma forma composicional. Esta última tende à cristalização em uma forma genérica (um gênero do discurso). E uma vez cristalizada, "a forma composicional relativamente estável" apresenta-se também como elemento coercitivo para os traços estilísticos. Assim, neste texto, ao observarmos cores, formas, disposições topológicas de figuras, entenderemos essas categorias como traços estilísticos, que podem ser próprios do gênero ou "apropriados" pelo autor.

Para analisar essas categorias, no todo significante que é o texto, faz-se necessário considerar primeiro sua dimensão sociocultural. Logo, não há como analisar capas de livros específicos sem antes tecermos considerações gerais sobre esse texto que se cristalizou em uma forma genérica.

\section{O gênero capa e contracapa de livros}

O livro, na atualidade, constitui um produto comercial submetido às leis de mercado, e, mais especificamente, às leis do mercado editorial. À obra, como um todo, é atribuída uma autoria e essa própria autoria constitui um dos "produtos" à venda - por isso, há, frequentemente, destaque conferido ao nome do autor na capa de um livro, sobretudo quando esse autor tornou-se uma referência em seu campo.

A despeito da "autoria à venda", o livro, em todo o seu projeto gráfico-editorial, possui vários "autores". No livro, na forma como ele é comercializado, não se tem apenas o texto que o "autor principal" escreveu, mas textos cuja autoria remete a outras "vozes", outros "nomes": a apresentação, comumente escrita e assinada por algum especialista convidado pela editora; o prefácio, que pode ser escrito pelos editores, pelos tradutores, pelos organizadores etc; notas da tradução, assinada pelos tradutores, quando se trata de uma obra traduzida; ensaios introdutórios etc. Podemos pensar, também, que um livro pode ser resultado de uma coletânea de textos ou artigos, cada um assinado por autores diferentes. Esses seriam os "autores" principais, ao passo que aqueles que assinam os textos auxiliares supracitados (Notas, Apresentação, Prefácio etc) seriam os autores "secundários".

Ao lado desses autores principais e secundários, englobando-os e "deixando-os" falar, existe um autor quase "anônimo", não fosse sua inscrição em várias partes do livro: trata-se da editora. Ao utilizarmos a expressão "quase anônimo" não queremos reduzir a importância da editora - pelo contrário: é ela quem determina formas específicas de recepção da obra, quem permite que os autores "primários e secundários" tenham voz. A editora - a autora "supra" - tem importância fundamental, mas, ao mesmo tempo, "apaga" ou reduz sua própria voz no destaque conferido ao autor principal, ao título da obra etc. Esse apagamento em detrimento do autor primário constitui a própria forma de funcionamento da esfera editorial.

Em suma, consideramos que a editora é a autora "supra" porque: 1. dá a voz a alguns e não a outros; 2. coordena os meios de organização do livro; 3 . coordena os meios de recepção. Um desses meios de recepção se dá através da forma como o livro é vendido. E uma das principais formas de vender o livro é através de sua capa e contracapa - o acesso primeiro do leitor ao material.

O projeto gráfico da capa e da contracapa obedece às leis de mercado e marketing e "reage" a uma visão determinada que se tem do público - o leitor. Essa imagem é apropriada como um valor social pela editora para promover e vender seu produto. Assim, é natural, por exemplo, que um livro destinado a um público infantil apresente, em sua capa, desenhos, cores diversas, algo próprio do universo infantil.

Observa-se que a capa e a contracapa de livros apresentam, a despeito de algumas variações, certa estruturação recorrente, passível de ser reconhecida e analisada. Essa estruturação, conforme afirmamos acima, envolve valores sociais apropriados pelo autor - a 
editora - e concretizados em um material que precisa "prender" a atenção de seu público - eis uma das razões pelas quais a capa de um livro não se vale apenas de texto verbal, mas de um texto verbo visual.

Essa materialidade - verbal e visual - apresenta elementos "fixos" (ou seja, que quase sempre estão presentes, a depender do público) e elementos variáveis. Em uma capa de livro, são, geralmente, elementos fixos: o título da obra, o nome da editora, e o nome do autor, associado a elementos "móveis", "opcionais", como fotografias, desenhos, informações sobre a edição, sobre os tradutores etc. A disposição desses elementos obedece a um projeto autoral que opta por destacar alguns elementos em detrimento de outros. A informação que está topologicamente "em cima" ou no centro sempre ocupa mais atenção que as informações dispostas em posições periféricas. Nessa posição periférica, geralmente encontramos o nome da editora. Temos, pois, quanto à categoria topológica, uma oposição "central x periférico".

A contracapa do livro, por sua vez, é a que mais apresenta elementos móveis. Como elemento fixo, temos praticamente O ISBN - International Standard Book Number. Segundo informações da Fundação Biblioteca Nacional, vinculada ao Ministério da Cultura do governo federal, o ISBN "é um sistema internacional padronizado que identifica numericamente os livros segundo o título, o autor, o país, a editora, individualizando-os inclusive por edição". ${ }^{96}$

$\mathrm{Na}$ contracapa, podemos apreender elementos móveis: Informações sobre a editora, fotografias, pinturas representadas, desenhos, citações de trechos da obra, trechos de avaliações feitas por especialistas, resumo da obra, título, biografia do autor, informações sobre a tradução, dentre outros. A lista de elementos móveis é imensa, e esses elementos podem estar - e geralmente estão - em conjunto. Assim, podemos ter em uma contracapa uma avaliação da obra feita por um especialista, um resumo da obra, uma fotografia do autor, indicação da tradução, além do ISBN. Podemos ter, por outro lado, apenas um resumo da obra juntamente com o ISBN.

Feitas essas considerações, passemos, no próximo tópico, a analisar algumas capas e contracapas de "Marxismo e filosofia da linguagem", atentando para o modo de funcionamento da esfera em que esse gênero circula - a esfera do mercado editorial, do comércio de livros - , e para os modos como o texto verbo-visual, em sua materialidade semiótica, condensa valores desse mercado, representações sobre o público, representações sobre a própria obra.

\section{Um olhar sobre capas e contracapas de "Marxismo e filosofia da linguagem"}

Neste tópico, analisamos capas e contracapas de "Marxismo e filosofia da linguagem" - a obra publicada pela Editora Hucitec, traduzida por Michel Lahud e Yara Frateschi Vieira e a obra publicada pela Editora 34, traduzida por Sheila Grillo e Ekaterina Vólkova Américo.

A questão das "obras disputadas" - referência à polêmica em torno de obras inicialmente publicadas por Volóchinov e Medviédev e posteriormente atribuídas a Bakhtin, sob motivos que ainda geram controvérsia - deve aqui ser abordada, pois essa questão determina modos de recepção das obras em análise e evidencia valores materializados nas capas e contracapas.

Sheila Camargo Grillo, linguista, eslavista e tradutora, após pesquisas arquivísticas realizadas na Rússia, afirma (GRILLO, 2016) que naquele país é amplamente divulgado que Volóchinov nada escreveu e que a obra "O método formal nos estudos literários", publicada pela primeira vez em Leningrado em 1928, sob a autoria de Pavel N. Medviédev, seria de Bakhtin.

96 Informação disponível em: http://www.isbn.bn.br/website/o-que-e-isbn, acesso: 26/06/2017, às 16:00 h. 
Todavia, essa ideia não é unânime e tem sido tema de muitos debates. Grillo (op. cit.), com base em Faraco (2009), apresenta três posições sobre a autoria das "obras disputadas". A primeira, adotada por Clark e Holquist, defende a autoria exclusiva de Bakhtin - este teria "cedido" os direitos de suas obras a seus amigos. Não há qualquer registro escrito que comprove essa "cessão" da autoria, e, conforme Grillo, o filólogo e semioticista Viatchesláv V. Ivánov, no início dos anos 1970, teria sido o responsável por divulgar a informação de que a autoria de várias obras assinadas por Volóchinov e Medviédev seria de Bakhtin.

Há uma segunda posição, que defende a "autoria original". Assim, os textos originalmente publicados por Volóchinov e Medviédev teriam sido, de fato, escritos e concebidos por esses autores e não por Bakhtin. A ideia de uma "cessão" de autoria, que teria levado a inclusão posterior de Bakhtin como autor de obras como "Marxismo e filosofia da linguagem" e "O método formal nos estudos litertários", seria resultado de um "engano", divulgado por pessoas como Viatchesláv V. Ivánov e pelo tradutor americano A. J. Werhrle, sem comprovações documentais. A respeito dessa segunda "teoria", Grillo (2016, p. 33) argumenta que "Diferentemente de Bakhtin, os trabalhos publicados sob os nomes de Medviédev e Volóchinov exibem uma terminologia marxista. Nesse sentido, há evidências históricas e teóricas de que Bakhtin nunca simpatizou com o marxismo".

A terceira posição defende uma coautoria em obras como "O método formal nos estudos literários", mantendo "os nomes originais da publicação seguidos de uma barra oblíqua, precedendo o nome de Bakhtin” (GRILLO, 2016, p. 35).

Alinhada à primeira posição - autoria de Bakhtin -, aparece a edição de "Marxismo e filosofia da linguagem" publicada no Brasil pela editora Hucitec. A primeira edição da obra foi publicada em 1979, a partir da tradução francesa de $1977^{97}$. Abaixo, reproduzimos a capa e a contracapa, lado a lado, para melhor visualização, da obra da Hucitec, em sua $13^{\circ}$ edição, datada de 2009.

Figura 1 - Capa e contracapa 1

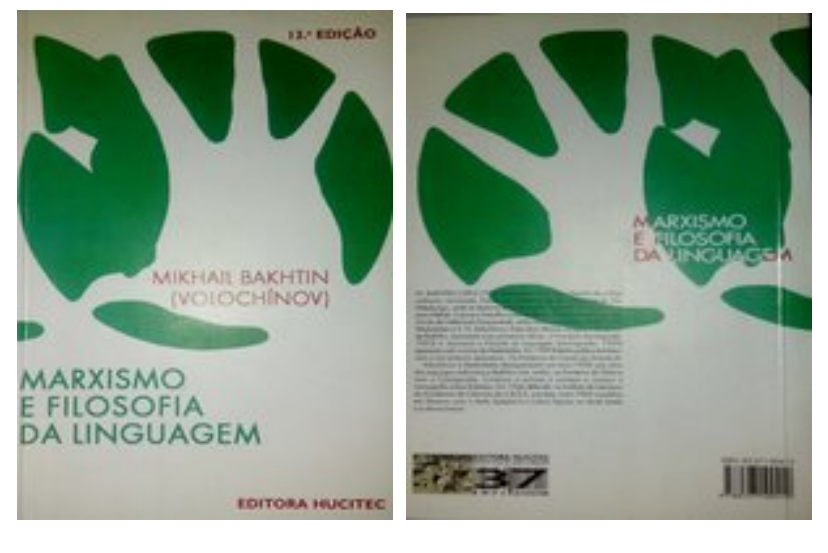

Fonte: arquivo pessoal.

Conforme afirmamos anteriormente, a editora assume a autoria do projeto gráficoeditorial da obra, incluindo a capa e contracapa, que são os primeiros elementos do livro a que tem o leitor contato (principalmente se considerarmos que, frequentemente, os livros encontram-se plastificados nas livrarias). Obviamente, designers são encarregados de produzir essa parte da obra, mas segundo critérios pré-estabelecidos pela editora, que detém os direitos autorais do projeto. Na obra cuja capa e contracapa estão acima reproduzidas, não é citado o nome do designer responsável pelo projeto gráfico.

Considerando primeiramente a dimensão sociocultural referida no quadro 2 deste artigo, temos uma relação entre interlocutores - editora (autor) / público acadêmico na área de

97 "Nota dos tradutores" na obra "Marxismo e filosofia da linguagem" publicada pela editora Hucitec. 
ciências humanas e sociais (leitor) - definida: 1. por valores de um mercado editorial; 2. por valores de um mercado editorial destinado a um público acadêmico específico. Projeta-se uma visão de leitor que provavelmente já conhece algo da obra, pois nenhuma outra informação mais detalhada (resumo, avaliações críticas, trechos da obra) é fornecida na contracapa. Os valores de mercado são perceptíveis desde a escolha das cores que irão compor o projeto gráfico-editorial (conforme mencionaremos adiante), mas estão ainda mais visíveis na contracapa, na margem inferior esquerda, onde é informado que, no ano de 2008, a editora completa 37 anos, o que leva ao leitor as imagens de "credibilidade", "confiança", "segurança" pela quantidade de anos que está a "marca" no mercado (em uma sociedade capitalista, baseada na ampla concorrência, é preciso ter esses atributos para permanecer quase quatro décadas no mercado). Ainda, confirmando os valores de mercado no produto "livro", temos um slogan: "Editora Hucitec. Para você ler e reler" - algo típico de empresas que comercializam bens e serviços. No que concerne ao espaço/tempo projetados no texto, encontra-se justamente a recepção à autoria deste que é um dos "textos disputados": a primeira posição, anticitada, que assume a autoria da obra originalmente publicada por Volóchinov a Bakhtin, é datada e marcada. Na década de 20 do século passado, a obra "era de Volóchinov", tinha sido publicada em seu nome. A atribuição da autoria a Bakhtin é posterior, resultado da "descoberta" desse autor no Ocidente, da ampla repercussão que os textos tiveram e que culminaram em pesquisas, indagações e entrevistas.

Observemos, de forma mais detalhada, elementos da segunda dimensão do quadro 2. Primeiramente, segundo afirmamos anteriormente, considerando a forma do gênero relativamente estabilizada, há elementos móveis e fixos na capa e na contracapa. Na capa, a inscrição de informações "extras" serve a propósitos específicos. Na capa em análise, não há nenhuma dessas informações, apenas as habituais: nome do autor, título da obra, editora e edição (esta última é citada a partir da segunda edição).

Esses elementos possuem uma materialidade verbo-visual, e essa própria materialidade exprime valores de mercado: como produto exposto à venda, um livro não poderia ter em sua capa "apenas texto", o "preto no branco" grafado da esquerda para a direita: essa diagramação não apela à visão, primeiro sentido acionado pelo público que consumirá o produto. Mesmo que uma capa de livro não se utilize de imagens, desenhos ou fotografias, o jogo de cores, a diagramação das letras, das formas das palavras apelam ao sentido da visão, evidenciando que estamos sim diante de um texto verbo-visual.

Como texto verbo-visual, atendendo a valores específicos, as informações são dispostas em categorias topológicas. Essas categorias estruturam-se segundo posições estratégicas que demarcam uma relação de sentido "central x periférico" / " informação mais relevante x informação menos relevante". Essa categoria, conforme citado, constitui traços estilísticos - e o estilo, segundo Bakhtin (2003 [1953]), está indissociavelmente ligado ao gênero. No gênero capa e contracapa de livro, ocupam posição secundária (geralmente as margens) informações sobre a editora, e posição primária (de destaque) informações sobre a obra e o autor. No texto em análise, na capa, o nome da editora e a edição estão alinhados à direta e essas informações ocupam as margens: a edição ocupa a margem superior; o nome da editora ocupa a margem inferior.

$\mathrm{Na}$ contracapa, o ISBN (informação secundária) sempre ocupa a margem. Mesmo informações que têm por finalidade promover a editora (no texto em análise, o slogan e a informação de que a editora comemora 37 anos), por serem informações referentes à editora e não ao autor da obra, ou ao título, ou ao conteúdo da obra - devem ocupar as margens. Assim, na contracapa da $13^{\circ}$ edição de "Marxismo e filosofia da linguagem" da Hucitec, o slogan da editora aparece na margem inferior esquerda.

Quanto à categoria cromática, observamos que essa categoria, além de ser um traço estilístico, também evidencia valores de mercado. Heller (2013), em pesquisa sobre as cores e 
as emoções que elas despertam, no âmbito do simbolismo psicológico e da tradição histórica, destaca que aqueles que trabalham com cores - artistas, designers gráficos, arquitetos etc utilizam diversas informações cromáticas na confecção de seus produtos.

Dentre as três cores com mais simbolismo nas tradições históricas, segundo Heller (2013), estão o azul, seguido pelo verde e depois o vermelho. Essas cores, portanto, provavelmente estão presentes em muitos produtos à venda - e sendo o livro um deles, a utilização dessas cores em projetos gráficos de capas e contracapas não é fortuita. No primeiro texto aqui analisado, na capa, há as cores verde e vermelha sobre o fundo branco. $\mathrm{Na}$ contracapa, além dessas cores, temos o preto utilizado para a impressão de um texto mais longo. O preto sobre o fundo branco também não é utilizado de forma fortuita. Observemos que essa cor serve justamente para a configuração de um texto mais longo (uma breve biografia de Bakhtin), que demanda mais tempo de leitura. Segundo Heller (2013), textos mais longos e com conteúdos desconhecidos, ao requerem mais tempo para compreensão, são lidos de perto. Assim, as cores "atrapalham" - o preto sobre o branco é mais legível. O contraste estabelecido, portanto, na categoria cromática da edição da Hucitec, é entre o verde $x$ o vermelho e o branco $x$ o preto.

Voltando à categoria topológica, temos, na capa, uma relação englobante $\mathrm{x}$ englobado. Há uma imagem abstrata, cujas formas não se completam por inteiro, de uma mão, que se forma a partir do contraste do verde sobre o branco. Essa imagem engloba o nome do autor "Mikhail Bakhtin (Volochínov)", que, impresso em vermelho, alinha-se à editora e à edição, também impressas em vermelho, ou seja, os traços de autoria - o "autor" da obra e a "autora supra" - encontram-se em vermelho. Na capa, o título "Marxismo e filosofia da linguagem" e a imagem estão em verde e englobam, portanto, o autor. Observemos, ainda, que o espaço ocupado pelo verde é superior ao vermelho: a obra, portanto, parece ter mais relevância que o próprio autor. Se consultarmos informações "dentro do livro", como as orelhas, constatamos que há muito mais ênfase conferida à obra e à sua qualidade que ao autor propriamente. Assim, na orelha, é notória a utilização de estruturas sintáticas passivas com omissão do agente da passiva ( ex: “(...) são alguns dos temas que o leitor encontrará, neste livro, discutidos, às vezes, com desenvoltura e perspicácia que não decepcionam") ou a atribuição de ações ao livro ou à publicação e não ao autor ("É, em meio à controvérsia de que era objeto de formalismo que se dá a sua publicação. $\mathrm{O}$ esforço, que nele se observa, para desenvolver uma filosofia da linguagem de fundamento marxista, sem as paranoias histéricas das receitas oficiais, é admirável").

Quanto à categoria eidética, há uma relação de oposição entre formas curvilíneas $\mathrm{x}$ formas retilíneas. A imagem abstrata de uma mão, formada pela junção de "manchas" verdes, em ângulos, sobre o fundo branco, contrapõe-se aos textos lineares "edição", "nome do autor", "nome da editora". Essa forma, presente na capa e na contracapa, além de englobar o nome do autor, conforme citado, causa certo "estranhamento" por sua incompletude (a ausência de ângulos determinando o contorno dos dedos e a sobreposição do dedo indicador, na capa, e do dedo mínimo, na contracapa). A mão é um traço humano, mas, no projeto gráfico, é um traço humano "incompleto", delineado por manchas. Esse projeto gráfico, devido à abstração das formas, traz em si temas com forte simbolismo: o humano, a incompletude - temas esses presentes em vários textos do Círculo de Bakhtin. Se esses temas são suscitados, devemos atentar, porém, primeiramente ao efeito da imagem no propósito de chamar a atenção do leitor para o livro. Assim, a imagem "captura" o leitor, causa estranhamento, convida-o a folhear as páginas, a adquirir o produto. $\mathrm{O}$ efeito de sentido da imagem, e, por extensão, de todo o projeto gráfico, é de subjetividade: não se sabe ao certo o que a imagem representa - um olhar interpretativo é convocado.

A respeito da autoria, a inclusão do nome de Volóchinov poderia levar a crer que a posição adotada quanto a essa "obra disputada" é a de uma coautoria. Essa crença é desfeita 
na própria contracapa da obra, na qual há uma pequena biografia de Bakhtin e nela lemos que Medviédev e Volóchinov assinaram suas primeiras obras. Na orelha do livro, ratifica-se essa posição: "Não são claras as razões efetivas que teriam levado Bakhtin a escolher o nome de um de seus discípulos para subscrever a autoria do livro". Logo em seguida, afirma-se: "O fato é que o leitor encontrará aqui vários pontos comuns com a Poética de Dostoievski e mesmo com a sua obra sobre Rabelais e a cultura popular". Assim, na interpretação da editora, mesmo não sendo clara a razão que levaria Bakhtin a ceder sua obra a Volóchinov, os vários pontos em comum entre "Marxismo e Filosofia da linguagem" e outras obras cuja autoria não é disputada reforçam a tese de que "Marxismo..." seria sim de Bakhtin. Devemos considerar, porém, que a edição francesa, a partir da qual foi feita a tradução da Hucitec, fez essa mesma opção (Bakhtin em primeiro lugar e Volóchinov entre parênteses).

Essa posição de V. Volóchinov entre "parênteses" é, em certo sentido, ambígua, incomum: várias obras têm dois (ou mais) autores, um autor e um coautor, mas poucas obras são publicadas atribuindo-se sua autoria a um nome, tendo outro nome, de outra pessoa, entre parênteses. Essa "posição de parênteses" inverte-se em outra capa, que surge responsivamente à edição da Hucitec. Trata-se da obra "Marxismo e fillosofia da linguagem" publicada pela editora 34, em 2017, traduzida por Sheila Grillo e Ekaterina Vólkova Américo. Vejamos a capa e a contracapa.

Figura 2 - Capa e contracapa 2.

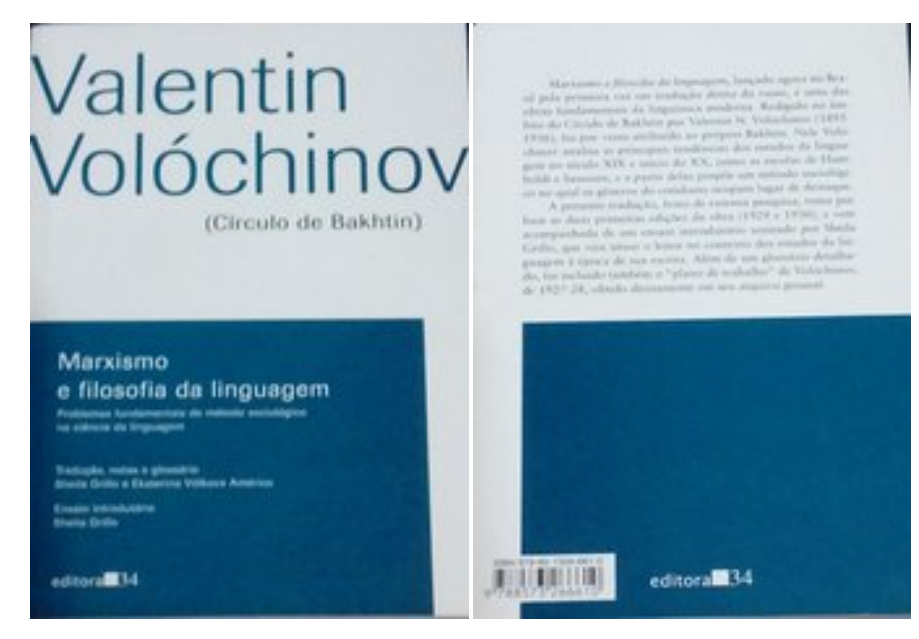

Fonte: arquivo pessoal.

Como na outra capa, temos uma relação entre autor/leitor mediada pelos valores de mercado, regulada pelo nicho acadêmico. Chama-nos a atenção, porém, a temporalidade projetada nessa capa, enquanto valor social a respeito dos modos de recepção da obra: a primeira edição é de 2017; a tese anteriormente defendida acerca da autoria de Bakhtin, desde o início controversa, como revela a cautela com que a Hucitec atribui a autoria de "Marxismo..." a Bakhtin ("Não são claras as razões efetivas...") é cada vez mais questionada. Em 2012, é publicada no Brasil a obra "Bakhtin desmascarado: história de um mentiroso, de uma fraude, de um delírio coletivo", a partir da tradução do francês "Bakhtine démasqué: histoire d'un menteur, d'une escroquerie et d'um délire collectif', de autoria de Jean-Paul Bronckart e Cristian Bota (BRONCKART; BOTA, 2012). Nessa obra, em tom incisivo afirma-se que Bakhtin mentira quanto à autoria das obras disputadas e, mais que isso, haveria cometido plágio em obras assinadas em seu nome. Há, portanto, a necessidade de pesquisas mais apuradas quanto à origem das obras disputadas. Essa necessidade projeta-se no texto em análise. 
Uma questão, referente aos valores de mercado, impõe-se: considerando que já se tinha uma obra (um produto à venda) traduzida desde 1979 no Brasil; que essa obra encontrava-se em sua $13^{\circ}$ edição; que já estava, portanto, "consolidada" em seu nicho, como "vender" outra tradução nesse mercado consolidado?

Primeiro, o apelo à autoria é evidente. $\mathrm{Na}$ análise da materialidade textual, como categoria topológica, vemos o nome "Valentin Volóchinov" na parte superior da capa, ocupando cerca de um terço ou mais do espaço desta capa. Segundo, há forte apelo à tradução. Observemos que nem na capa nem na contracapa da obra da Hucitec há indicações sobre a tradução. Essa informação apenas é fornecida no interior da obra, como mais comumente ocorre. No livro da editora 34, porém, logo na capa (lembremos: o primeiro contato que tem o leitor com o "produto" livro) encontra-se a informação de que a tradução foi feita por Sheila Grillo e Ekaterina Vólkova Américo. Na contracapa, reforça-se esse apelo à tradução e, sobretudo, ao ineditismo e à relevância dessa nova tradução, feita diretamente a partir do russo: "Marxismo e filosofia da linguagem, lançado agora no Brasil pela primeira vez em tradução direta do russo" / "A presente tradução, fruto de extensa pesquisa...". Observemos que, na primeira citação, a atualidade e o ineditismo do produto é enfatizado por duas expressões adverbiais ("agora" e "pela primeira vez"). Essas expressões reforçam a ideia: você, leitor, consumidor das obras do Círculo de Bakhtin, está diante de um novo produto: mais atual e que apresenta um diferencial - a tradução direta do russo, e não mediada por outras línguas, como ocorre com a obra da Hucitec. O "diferencial" de um produto é o que, de fato, o faz ser consumido, tornar-se objeto de desejo do mercado consumidor. E como outro diferencial, além do apelo à atualidade, ao ineditismo da tradução, há o apelo ao trabalho que envolveu a elaboração da obra ("fruto de extensa pesquisa"). Por fim, como qualidade diferenciada do produto, há a indicação de que nesta obra encontram-se notas um glossário e um ensaio introdutório. Todas essas informações estão presentes logo na capa da obra, o que não é muito comum, a não ser que se queira enfatizá-las, como, de fato, aqui ocorre.

Uma análise mais detalhada da materialidade verbo-visual da capa e da contracapa mostra-nos, além do fato de o nome do autor ocupar maior destaque na capa, que as cores (categoria cromática) estão a serviço desse propósito. Observemos que três cores compõem a capa e a contracapa: branco, azul (em um tom escuro) e preto. Topologicamente, há a oposição, na capa, entre o nome do autor, juntamente com a inscrição "Círculo de Bakhtin" em negro e entre parênteses, e um quadro também em azul que ocupa cerca de metade da página. $\mathrm{O}$ azul do quadro serve como pano de fundo para a inscrição do título da obra, de um subtítulo (que não aparecia na capa da Hucitec), e de informações sobre a tradução, notas e glossários, ensaio introdutório e o nome da editora na margem inferior esquerda (posição periférica, portanto). Essas informações - tradução, notas, etc - estão "englobadas" pelo quadro (categoria eidética), ao passo que o nome "Valentin Volóchinov" não é englobado por nada. Notemos que a cor do quadro é a mesma cor do nome do autor, que está em destaque. Se houvesse um contraste de cores (ex: o nome do autor em uma cor e o quadro em outra), haveria uma disputa pela atenção visual do leitor, e ganharia essa disputa aquela cor que mais se destacasse sobre o fundo branco. Estando o nome do autor e o quadro impressos sobre o mesmo tom, e sendo as informações impressas, no quadro, em branco, que contrasta com o azul desse quadro (mas que tem menos destaque visualmente), o nome do autor ganha mais destaque. Há uma oposição: azul sobre fundo branco x branco sobre fundo azul, que é interpretada como: maior relevância x menor relevância, devido à melhor legibilidade, para o olho humano, do azul escuro sobre o branco.

Quanto à categoria eidética, nota-se que, diferentemente da capa da Hucitec, construída a partir de oposições entre formas curvilíneas x retilíneas, evocando efeitos de subjetividade, a capa da editora 34 é totalmente estruturada a partir de ângulos retos, sem 
imagens. Não há, portanto, convites à interpretação, como o faz a editora Hucitec. Na capa da editora 34, desde o predomínio de uma cor eminentemente fria (o azul), o apelo é à objetividade; o efeito de sentido evocado é o de sobriedade. As duas capas, dessa forma, estão em diálogo, em uma polêmica travada acerca da autoria, e em sua materialidade trazem essa oposição: contraste de formas x unicidade de formas retilíneas, subjetividade x objetividade.

Acerca dessa polêmica, destaque especial é conferido, na capa da editora 34, ao nome de "Valentin Volóchinov" - um "diferencial" no produto, dado que o leitor estava acostumado com o nome de Bakhtin associado a "Marxismo e filosofia da linguagem". Todavia, notemos a inscrição, entre parênteses, da expressão "Círculo de Bakhtin". Essa inscrição deve ser interpretada, pois condensa valores sociais na materialidade do texto.

$\mathrm{Na}$ orelha do livro, assinada por Betth Brait - renomada pesquisadora brasileira sobre Bakhtin e o Círculo -, após um parágrafo que explica a necessidade de uma nova tradução da obra, isto é, que explica um dos "diferenciais do produto" ("No estágio atual dos estudos bakhtinianos, as (re) traduções, no Brasil e no exterior, devem-se à consciência de que o pensamento dialógico exige o conhecimento dos contextos de produção e recepção.." / "Na confluência entre esses dois elementos está o fato de que os (re) tradutores são, hoje, especialistas...”), há, também, uma explicação acerca da inscrição da autoria ("o autor é Valentin Nikoláievitch Volóchinov" / "Entretanto, considerando a forte colaboração existente entre Bakhtin e Volóchinov na década de 1920, e seguindo o mesmo princípio adotado em $O$ método formal, a expressão "Círculo de Bakhtin" complementa a autoria").

Essa explicação, apesar de assumir Volóchinov como autor (ao menos como "autor principal"), evidencia que a polêmica acerca da autoria desse que é um dos mais famosos "textos disputados" ainda ressoa. Existem e existiram muitos grupos de estudo e pesquisa, e esse não é um motivo para a inscrição, na capa de um livro, do "círculo", do "grupo de pesquisa" a que se vincula ou se vinculou determinado autor, abaixo de seu nome. Logo, essa insistência na inscrição do "Círculo de Bakhtin" traz em si os "ecos" da polêmica da autoria, e constitui uma reação-resposta a essa polêmica. Ao mesmo tempo, pensando especificamente em certo leitor "acostumado" a ver o nome de Bakhtin associado à obra, a inscrição "Círculo de Bakhtin" responde, também, a esse leitor. Por fim, ainda refletindo sobre o mercado e a relação com o leitor, o destaque conferido ao nome de Volóchinov, juntamente com a expressão "Círculo de Bakhtin", pode aguçar a curiosidade, levando à aquisição do produto.

\section{Considerações finais}

Uma questão que, a nosso ver, tem de nortear a análise de textos refere-se aos modos de funcionamento - às "leis de funcionamento" (MEDVIÉDEV, 2016) - de determinada esfera, observando-se a relação entre a forma, o material e os sentidos sociais do texto, objeto semiótico, que tende à estabilização genérica. Nesse sentido, procuramos interpretar a citação que, de tão repetida tornou-se quase que uma "fórmula", segundo a qual um gênero é um tipo relativamente estável de enunciado, que reflete as finalidades de seu campo, pelo tema, pelo estilo e pela composição (BAKHTIN, 2003 [1953]). Se nos determos mais atentamente a essa citação de Bakhtin, veremos que o autor confere ênfase ao campo discursivo (às suas finalidades, às suas condições singulares) no qual se constituem os enunciados e não a formas "engessadas" de enunciados.

Assim, um caminho, "uma porta de entrada" para a análise reside nos valores, nas condições e finalidades, na temporalidade refletida e refratada no texto, dentro de sua esfera social. Ao mesmo tempo, percebemos que a materialidade textual, em sua especificação semiótica, traz em si condensada os valores, as condições, a temporalidade supracitada. 
Considerando que o Círculo de Bakhtin debruçou-se sobretudo em textos de materialidade verbal, faz-se necessário investigar como outras materialidades (verbo-visuais, pictóricas, multissemióticas etc) funcionam em determinada esfera.

Neste artigo, devido às limitações espaço/temporais que nos são impostas, analisamos brevemente duas capas e contracapas de livro - textos verbo-visuais -, evidenciando como essa materialidade específica serve aos propósitos de sua esfera (ao mercado editorial, que busca no próprio objeto à venda fazer sua "propaganda" por meio de categorias cromáticas topológicas e eidéticas), condensa valores de um tempo (o valor de mercado e de consumo, através do apelo à diferenciação do produto), estabelece modos específicos de recepção do texto.

\section{REFERÊNCIAS}

BAKHTIN, M. Os gêneros do discurso. In: Estética da criação verbal. Tradução de Paulo Bezerra. 4 ed. São Paulo: Martins Fontes, 2003 [1953]. p. 261-306.

O problema do texto na linguística, na filologia e em outras ciências humanas.

In:_ Estética da criação verbal. 4. ed.Tradução de Paulo Bezerra. São Paulo: Martins Fontes, 2003 [1959-1961], p. 307-335.

. Para uma filosofia do ato responsável. Tradução de Valdemir Miotello e Carlos

Alberto Faraco. São Carlos: Pedro 7 João Editores, 2010, 155 p. (VOLOCHÍNOV). Marxismo e filosofia da linguagem. Tradução de Michel

Lahud e Yara Frateschi Vieira. 13 ed. São Paulo: Hucitec, 2009, 203 p.

. O problema do conteúdo, do material e da forma na criação literária. In:

Questões de literatura e de estética: a teoria do romance. 5 ed. São Paulo: Hucitec, 2002, p. 13-70.

BRONCKART, J.P.; BOTA, C. Bakhtin desmascarado: história de um mentiroso, de uma fraude, de um delírio coletivo. Tradução de Marcos Marcionilo. São Paulo: Parábola editorial, 2012, 509 p.

FARACO, C. A. Linguagem \& diálogo: as ideias linguísticas do círculo de Bakhtin. São Paulo: Parábola editorial, 2009, 168 p.

. O problema do conteúdo, do material e da forma na arte verbal. In: BRAIT, B.

(Org.). Bakhtin: dialogismo e polifonia. São Paulo: Contexto, 2016, p. 95-112.

GRILLO, S. C. A obra em contexto: tradução, história e autoria. In: MEDVIÉDEV, P. N. O

método formal nos estudos literários: introdução crítica a uma poética sociológica.

Tradução de Sheila Camargo Grillo e Ekaterina Vólkova Américo. São Paulo: Contexto, 2016, p.19-38.

HELLER, E. A psicologia das cores: como as cores afetam a emoção e a razão. Tradução de Maria Lúcia Lopes da Silva. São Paulo: Gustavo Gili, 2013, 311 p.

MEDVIÉDEV, P. N. O método formal nos estudos literários: introdução crítica a uma poética sociológica. Tradução de Sheila Camargo Grillo e Ekaterina Vólkova Américo. São Paulo: Contexto, 2016, 269 p.

OLIVEIRA, A. C. de. Semiótica plástica. São Paulo: Hacker, 2004.

SILVA, F. M. da. Expressão e conteúdo: articulações do texto sincrético. In: CORTINA, A.; SILVA, F. M. da. (Orgs.). Semiótica e comunicação: estudo sobre textos sincréticos.

Araraquara, SP: Cultura acadêmica, 2014, p. 231-260.

VOLÓCHINOV, V. N. (1930). Estrutura do enunciado. (Tradução de Ana Vaz, para fins didáticos). Disponível em: https://pt.scribd.com/document/81664106/BAKHTIN-EstruturaDo-Enunciado. Acesso: 09/07/2017, às 16:36h. 
. (1926). Discurso na vida e discurso na arte. (Tradução de Carlos Aolberto Faraco e Cristovão Tezza, para fins didáticos). Disponível em: http://www.uesb.br/ppgcel/DiscursoNa-Vida-Discurso-Na-Arte.pdf. Acesso: 09/07/2017, às 16:41h.

. Marxismo e filosofia da linguagem: problemas fundamentais do método sociológico na ciência da linguagem. Tradução de Sheila Grillo e Ekaterina Vólkova Américo. São Paulo: editora 34, 2017, 376 p.

Recebido em 03/08/2017

Aceito em 20/11/2017 